\title{
A Study on Significance of Job Satisfaction and Commitment of Employees in Small Scale Industries
}

\author{
Dr. J. S. V. Gopala Sarma \\ Department of Commerce \& Management Studies and Andhra University
}

\begin{abstract}
Efficient management of human resources is a crucial factor in determining the growth and prosperity of business enterprises. This is particularly true in the case of small industry where the owners are forced to have a close and more personal association with their employees. In order to build up loyal, efficient and committed work force, small scale organizations should pay adequate attention to hiring, training and employee development activities and undertake systematic human resource practices on a long term basis. This paper explains two major areas from my study. The first one is Job Satisfaction and second one is commitment of employees in small scale industries. This paper highlights the role of HR Practices relating to job satisfaction and commitment of employees in the small scale industries. The main source of information, however, is primary data collected through the questionnaires* meant for employees and employers. In view of the large number of small scale units in Visakhapatnam, it has been decided to go for a sampling method.
\end{abstract}

Keywords: Job Satisfaction and Commitment.

\section{Introduction}

Human beings are very complex in their psychological make up and hence, managers cannot influence employees' inner states directly. They can, however, create work environments that encourage quality performance. Physical working conditions and reward systems should therefore be designed carefully and used effectively to encourage individuals to reach organizational goals. Incentives such as fair compensation, job security, promotions and challenging work are always considered as important for the motivation of employees in small industry. In the present chapter, an attempt has been made to examine the nature of work environment that prevails in small industry; the psychological environment that prompts people to peak performance, and the important reasons that generally influence the satisfaction level of employees in small industry. Finally an endeavour has also been made to study the commitment of employees in small industry.

\section{Objectives Of The Study}

(i) The present study has been carried out with the following specific objectives: To analyze the job satisfaction existing in the units, and understand the commitment of employees towards their units.

ii) To offer suggestions for creating a good HR culture in small scale units by practicing sound and effective HR practices

\section{Methodology And Sampling}

In view of the large number of small scale units in Visakhapatnam, it has been decided to go for a sampling method.

Selection of Sample Employers

For the purpose of administering the questionnaire among the Employers, we have taken as many employers as there are sample units. Since 54 units are taken as sample units from the five dominant industrial groups, 54 employers are taken to represent their respective units and the questionnaire has been administered among them. All the employers responded to the questionnaires.

Selection of Sample Employees

There are 624 employees totally working in the 54 sample units covered in the study.

The number of employees working in each category of the industrial groups is shown in the Table1.1 and the number of employers in each category of the industrial groups is shown in the Table1.2. 
TABLE 1.1

SAMPLE SIZE OF RESPONDENT EMPLOYEES

\begin{tabular}{|l|l|l|l|l|}
\hline $\begin{array}{l}\text { Industry } \\
\text { Groups }\end{array}$ & $\begin{array}{l}\text { Sample } \\
\text { Units }\end{array}$ & $\begin{array}{l}\text { No. of } \\
\text { Employees }\end{array}$ & $\begin{array}{l}\mathbf{5} \text { 0\% Sample } \\
\text { Size of } \begin{array}{l}\text { Actual No. of } \\
\text { Employees }\end{array}\end{array}$ & $\begin{array}{l}\text { Employees } \\
\text { Responded }\end{array}$ \\
\hline Agro based & 7 & 78 & 39 & $32^{*}$ \\
\hline Food & 7 & 114 & 57 & 57 \\
\hline $\begin{array}{l}\text { Chemical \& } \\
\text { Engineering }\end{array}$ & 20 & 230 & 115 & 115 \\
\hline Electrical & 14 & 142 & 71 & $51^{*}$ \\
\hline Electronics & 6 & 60 & 30 & 30 \\
\hline Total & $\mathbf{5 4}$ & $\mathbf{6 2 4}$ & $\mathbf{3 1 2}$ & $\mathbf{2 8 5 *}$ \\
\hline \multicolumn{5}{|l}{ *A few employees not responded to the questionnaire } \\
Source: Records of DIC, Visakhapatnam.
\end{tabular}

TABLE 1.2

SAMPLE SIZE OF SMALL SCALE UNITS

\begin{tabular}{|l|l|l|}
\hline Industry Groups & $\begin{array}{l}\text { Small Units in the } \\
\text { Universe }\end{array}$ & $\begin{array}{l}\text { Sample Units of } \\
\text { 10 percent }\end{array}$ \\
\hline Agro based & 65 & 7 \\
\hline Food & 70 & 7 \\
\hline $\begin{array}{l}\text { Chemical } \\
\text { Engineering }\end{array}$ & 200 & 20 \\
\hline Electrical & 140 & 14 \\
\hline Electronics & 60 & 6 \\
\hline Total & $\mathbf{5 4 0}$ & $\mathbf{5 4}$ \\
\hline
\end{tabular}

Source: Records of DIC, Visakhapatnam.

Since only a few employees work in each unit, a sample size of 50 percent was considered reasonable and accordingly sample size of respondents has been arrived at and shown in the table. However, the actual number of respondents was slightly short of the required sample size because of the failure of seven employees in Agro-based industry and 20 employees in Electrical industry to respond to the questionnaires due to their personal reasons and due to their non availability in spite of repeated visits of the researcher. As a result the final sample size of employees remained at 285 in all the categories of units covered viz., Agro-based, Food, Chemical \& Engineering, Electrical and Electronics. In selecting the respondents from each unit, stratified sampling method has been followed. First the workers were classified on the basis of their skill into skilled, semi-skilled and unskilled categories. Following stratified sampling method, the respondent employees were selected from all the categories to ensure representation of all employees.

\section{TOOLS OF ANALYSIS}

For analyzing and interpreting the data so collected from different sources, simple statistical techniques like averages and percentages are used.

\section{JOB SATISFACTION}

Job satisfaction refers to a person's feeling of satisfaction on the job. It represents a constellation of a person's attitudes toward the job. It is a function of satisfaction with different aspects of the job, such as nature of work, supervisor, co-workers, leadership style etc., and of the particular importance one attaches to these respective factors. Job satisfaction is rather a general feeling of contentment with the various facets of job and work environment and hence all these facets have been examined on the basis of opinions of employees in the selected units covered in the study with the help of table 1.3

i) Work

The table 1.3 shows that above two-fifth (40.35 per cent) of the employees in all small scale industries stated that they are neither satisfied nor dissatisfied with their work. However, 33.33 per cent of the employees expressed that they are dissatisfied with their work. Whereas, 26.32 per cent of the employees are stated that they are satisfied with their work. It may be concluded that large per cent of the employees in Agro-based, 
Chemical \& Engineering industries expressed that they are neither satisfied nor dissatisfied with their work. Large per cent of the employees in Food and Electrical industries expressed that they are dissatisfied with their work. Majority of the employees in Electronics industries stated that they are satisfied with their work.

\section{ii) Supervisor}

It can be stated that above two-fifth (40.70 per cent) of the employees in all small scale industries stated that they are satisfied with supervisor. However, 30.18 per cent of the employees expressed that they are dissatisfied with supervisor. Whereas, 29.12 per cent of the employees stated that they are neither satisfied nor dissatisfied with supervisor. It may be concluded that majority of the employees in Food and Electronics industries are expressed that they are satisfied with the behavior of supervisor. 40.63 per cent of the employees in Agro-based industries expressed that they are satisfied with the behavior of supervisor. 36.52 per cent of the employees in Chemical \& Engineering and 41.18 per cent of the employees in Electrical industries stated that they are dissatisfied with the behavior of the supervisor.

\section{iii) Co-workers}

It can be observed that 47.72 per cent of the employees in all small scale industries stated that they are satisfied with co-workers. However, 27.02 per cent of the employees expressed that they dissatisfied with coworkers. Whereas, 25.26 per cent of the employees stated that they are neither satisfied nor dissatisfied with coworkers. It may be concluded that majority of the employees in Agro-based, Food and Chemical\& Engineering industries expressed that they are satisfied with co-workers. 45.10 per cent of the employees in Electrical industries expressed that they are dissatisfied with co-workers. 40.00 per cent of the employees in Electronics industries stated that they are neither satisfied nor dissatisfied with co-workers.

\section{iv) Employer style and functioning}

It can be seen from the study that 37.89 per cent of the employees in all small scale industries stated that they are neither satisfied nor dissatisfied with employer style. While 36.14 per cent of the employees expressed that they are dissatisfied with employer style, 25.97 per cent of the employees expressed that they are satisfied with employer style. It may be further observed that 40.63 per cent of the employees in Agro-based industries expressed that they are satisfied with employer style. A large per cent of the employees in Food and Electronics industries expressed their dissatisfaction with employer style. A large per cent of the employees in Chemical \& Engineering and Electrical industries stated that they are neither satisfied nor dissatisfied with employer style.

\section{v) Work environment}

It can be observed from the table that 36.14 per cent of the employees in five categories of sample industries stated that they are moderate with work environment. However, 34.74 per cent of the employees are expressed that they are unfavorable with work environment. Whereas, 29.12 per cent of the employees stated that they are congenial with work environment. It may be concluded that large per cent of the employees in Agro-based and Food industries expressed that they are unfavorable with work environment. Large per cent (46.09 per cent) of the employees in Chemical \& Engineering industries expressed that they are moderate with work environment. Large per cent of the employees in Electrical and Electronics industries stated that they are congenial with work environment. 


\begin{tabular}{|c|c|c|c|c|c|c|c|c|c|c|c|c|c|c|c|c|c|c|}
\hline VARIOUS FAC & TOR & $\mathbf{O F}$ & ГHE & JOB & AND & EM & $\begin{array}{l}\text { ABL } \\
\mathrm{LOY}\end{array}$ & $\begin{array}{l}\text { E } 1.3 \\
\text { EE S }\end{array}$ & ATI & SFAC & CTIO & $\mathbf{N}$ & & & & & & \\
\hline \begin{tabular}{|l|} 
Various \\
factors of the \\
Job
\end{tabular} & Agro-bs & & & Food & & & Chemica & \& Engg & & Electrics & & & Electron & & & Total $\mathrm{N}=$ & $=285$ & \\
\hline & s & $\mathrm{N}$ & DS & s & $\mathrm{N}$ & DS & s & $\mathrm{N}$ & DS & s & $\mathrm{N}$ & DS & s & $\mathrm{N}$ & DS & $s$ & $\mathrm{~N}$ & DS \\
\hline Work & $\stackrel{9}{(28.13)}$ & $\begin{array}{l}13 \\
(40.63) \\
\end{array}$ & $\begin{array}{l}10 \\
(3125)\end{array}$ & $\begin{array}{l}14 \\
(2456)\end{array}$ & $\begin{array}{l}19 \\
(33,33) \\
\end{array}$ & \begin{tabular}{|l|}
24 \\
$(42.11$ \\
\end{tabular} & $\begin{array}{l}18 \\
(15.65)\end{array}$ & \begin{tabular}{|l|l}
65 \\
$(56.52$ \\
$5^{2}$
\end{tabular} & \begin{tabular}{|l|}
32 \\
$(27.8$ \\
$3)$ \\
\end{tabular} & $\begin{array}{l}18 \\
(3529\end{array}$ & $2^{12}(23.53$ & \begin{tabular}{|l|}
21 \\
$(41.1$ \\
$8)$ \\
\end{tabular} & \begin{tabular}{|l|}
16 \\
$(53.33)$ \\
\end{tabular} & \begin{tabular}{|l|}
6 \\
$(20.0$ \\
$0)$ \\
\end{tabular} & \begin{tabular}{|l|}
8 \\
$(26.6$ \\
$7)$ \\
\end{tabular} & $\begin{array}{l}75 \\
(2632)\end{array}$ & $\begin{array}{l}115 \\
(40,35)\end{array}$ & $\begin{array}{l}95 \\
(3333)\end{array}$ \\
\hline Supervisor & $\begin{array}{l}13 \\
(40.63)\end{array}$ & $\begin{array}{l}11 \\
(3437)\end{array}$ & $\begin{array}{l}8 \\
(25.00)\end{array}$ & $\begin{array}{l}30 \\
(52.63\end{array}$ & $\begin{array}{l}17 \\
(29.83)\end{array}$ & )$^{10}(17.54$ & $\begin{array}{l}40 \\
(34.78)\end{array}$ & $\begin{array}{l}33 \\
(28.70 \\
)^{2}\end{array}$ & $\begin{array}{l}42 \\
(36.5 \\
2)\end{array}$ & $\frac{12}{(23.53)}$ & )$^{18}$ & \begin{tabular}{|l|}
21 \\
$(41.1$ \\
$8)$
\end{tabular} & $\begin{array}{l}21 \\
(70.00)\end{array}$ & $\begin{array}{l}4 \\
(133 \\
3)\end{array}$ & \begin{tabular}{|l|}
5 \\
$(16.6$ \\
$7)$
\end{tabular} & $\begin{array}{l}116 \\
(40.70)\end{array}$ & $\begin{array}{l}83 \\
(29.12)\end{array}$ & $\begin{array}{l}86 \\
(30.18)\end{array}$ \\
\hline Co-workera & $\begin{array}{l}18 \\
(56.25)\end{array}$ & 8 & $\begin{array}{l}6 \\
(18.75)\end{array}$ & $\begin{array}{l}35 \\
(61.40)\end{array}$ & $\begin{array}{l}14 \\
(24.56)\end{array}$ & $\begin{array}{l}8 \\
(14.04 \\
\end{array}$ & $\begin{array}{l}60 \\
(52.17)\end{array}$ & $j^{23}$ & $\begin{array}{l}32 \\
(27.8 \\
3) \\
\end{array}$ & $\begin{array}{l}13 \\
(25.49)\end{array}$ & $\begin{array}{l}15 \\
(29.41 \\
)^{2}\end{array}$ & \begin{tabular}{|l|}
23 \\
$(45.1$ \\
$0)$ \\
\end{tabular} & $\begin{array}{l}10 \\
(33.33)\end{array}$ & $\begin{array}{l}12 \\
(40.0 \\
0)\end{array}$ & \begin{tabular}{|l|}
8 \\
$(26.6$ \\
$7)$ \\
\end{tabular} & $\begin{array}{l}136 \\
(47.72)\end{array}$ & $(25.26)$ & $\begin{array}{l}77 \\
(27.02)\end{array}$ \\
\hline $\begin{array}{l}\text { Employer } \\
\text { style and } \\
\text { functioning }\end{array}$ & $\frac{13}{(40.63)}$ & $\begin{array}{l}10 \\
(3125)\end{array}$ & $\stackrel{9}{(28.12)}$ & $\begin{array}{l}17 \\
(29.83)\end{array}$ & $\begin{array}{l}15 \\
(26.32)\end{array}$ & $\begin{array}{l}25 \\
(43.85\end{array}$ & $\begin{array}{l}23 \\
(20.00)\end{array}$ & $\int^{55}(47.83$ & $\begin{array}{l}37 \\
(32.1 \\
7)\end{array}$ & $\begin{array}{l}10 \\
(19.61)\end{array}$ & $\begin{array}{l}23 \\
(45.10 \\
)^{2}\end{array}$ & $\begin{array}{l}18 \\
(352 \\
9)\end{array}$ & $\begin{array}{l}11 \\
(36.67)\end{array}$ & $\begin{array}{l}5 \\
(16.6 \\
7)\end{array}$ & $\begin{array}{l}14 \\
(46.6 \\
6)\end{array}$ & $\begin{array}{l}74 \\
(2597)\end{array}$ & $\begin{array}{l}108 \\
(37.89)\end{array}$ & $\begin{array}{l}103 \\
(36.14)\end{array}$ \\
\hline $\begin{array}{l}\text { Work } \\
\text { environment }\end{array}$ & $\begin{array}{l}8 \\
(25.00)\end{array}$ & $\begin{array}{l}11 \\
(3438)\end{array}$ & $\begin{array}{l}13 \\
(40.62)\end{array}$ & $\begin{array}{l}13 \\
(22.81)\end{array}$ & $\begin{array}{l}15 \\
(2632)\end{array}$ & $\begin{array}{l}29 \\
(50.87\end{array}$ & $\begin{array}{l}22 \\
(19.13)\end{array}$ & $\begin{array}{l}53 \\
(46.09\end{array}$ & $\begin{array}{l}40 \\
(34.7 \\
8)\end{array}$ & $\begin{array}{l}21 \\
(41.18)\end{array}$ & $\begin{array}{l}16 \\
(31.37\end{array}$ & \begin{tabular}{|l|}
14 \\
$(27.4$ \\
$5)$
\end{tabular} & $\begin{array}{l}19 \\
(63.33)\end{array}$ & $\begin{array}{l}8 \\
(26.6 \\
7)\end{array}$ & \begin{tabular}{|l|}
3 \\
$(10.0$ \\
$0)$
\end{tabular} & $\begin{array}{l}83 \\
(29.12)\end{array}$ & $\begin{array}{l}103 \\
(36.14)\end{array}$ & $\begin{array}{l}99 \\
(34.74)\end{array}$ \\
\hline $\begin{array}{l}\text { Promotion } \\
\text { al } \\
\text { opportunit } \\
\text { ies }\end{array}$ & $\begin{array}{l}10 \\
(3125)\end{array}$ & $\begin{array}{l}14 \\
(43.75)\end{array}$ & $\begin{array}{l}8 \\
(25.00)\end{array}$ & $\begin{array}{l}15 \\
(2632)\end{array}$ & ${ }_{(31.58)}^{18}$ & $\begin{array}{l}24 \\
(42.11\end{array}$ & $\begin{array}{l}20 \\
(1739)\end{array}$ & $\begin{array}{l}55 \\
(47.83 \\
)^{2}\end{array}$ & $\begin{array}{l}40 \\
(34.7 \\
8)\end{array}$ & $\frac{12}{(23.53)}$ & )$^{20}(3922$ & \begin{tabular}{|l|}
19 \\
$(372$ \\
$5)$
\end{tabular} & $\begin{array}{l}16 \\
(5333)\end{array}$ & $\begin{array}{l}6 \\
(20.0 \\
0)\end{array}$ & $\begin{array}{l}8 \\
(26.6 \\
7)\end{array}$ & $\begin{array}{l}73 \\
(25.61)\end{array}$ & $\begin{array}{l}113 \\
(39.65)\end{array}$ & $\begin{array}{l}99 \\
(34.74)\end{array}$ \\
\hline $\begin{array}{l}\text { Compensati } \\
\text { on }\end{array}$ & $\begin{array}{l}8 \\
(25.00)\end{array}$ & $\begin{array}{l}13 \\
(40.63)\end{array}$ & $\operatorname{li}_{(3438)}$ & $\begin{array}{l}13 \\
(22.81)\end{array}$ & (29.83) & $\begin{array}{l}27 \\
(47.36\end{array}$ & $\begin{array}{l}28 \\
(2435)\end{array}$ & )$^{53}+46.09$ & $\begin{array}{l}44 \\
(38.2 \\
6)\end{array}$ & $\stackrel{9}{(17.65)}$ & )$^{18}$ & $\begin{array}{l}24 \\
(47.0 \\
6)\end{array}$ & $\begin{array}{l}14 \\
(46.67)\end{array}$ & $\begin{array}{l}4 \\
(133 \\
3)\end{array}$ & $\begin{array}{l}12 \\
(40.0 \\
0)\end{array}$ & $\begin{array}{l}72 \\
(2526)\end{array}$ & $\begin{array}{l}105 \\
(36.84)\end{array}$ & $\begin{array}{l}118 \\
(41.40)\end{array}$ \\
\hline Job security & $\stackrel{9}{(28.13)}$ & $\frac{12}{(3750)}$ & $\begin{array}{l}11 \\
(3437)\end{array}$ & $\begin{array}{l}13 \\
(22.81)\end{array}$ & $\begin{array}{l}15 \\
(26.32)\end{array}$ & ${ }^{29}(50.87$ & $\begin{array}{l}18 \\
(15.65)\end{array}$ & $\begin{array}{l}51 \\
(44,35\end{array}$ & $\begin{array}{l}46 \\
(40.0 \\
0)\end{array}$ & $\begin{array}{l}10 \\
(19.61)\end{array}$ & )$^{16}$ & $\begin{array}{l}25 \\
(490 \\
2)\end{array}$ & $\begin{array}{l}14 \\
(46.67)\end{array}$ & $\begin{array}{l}4 \\
(13.3 \\
3)\end{array}$ & $\begin{array}{l}12(4 \\
0.00)\end{array}$ & $\begin{array}{l}64 \\
(22.46)\end{array}$ & $\begin{array}{l}98 \\
(3439)\end{array}$ & $\begin{array}{l}123 \\
(43.15)\end{array}$ \\
\hline
\end{tabular}

Note: (1) $\mathbf{S}=$ Satisfied $\mathbf{N}=$ Neutral $\mathrm{DS}=$ Dissatisfied(2)

Figures in percentage indicate percentage to total (285) when viewed horizontally

\section{vi) Promotional Opportunities}

It can be stated from the study that 39.65 per cent of the employees in five categories of sample industries are stated that they are enjoyed with fair promotional opportunities. 34.74 per cent of the employees expressed that they are not enjoyed with promotional opportunities in their industries. 25.61 per cent of the employees are stated that they are enjoyed with good promotional opportunities. It may be concluded that large per cent of the employees in Agro-based, Chemical \& Engineering and Electrical industries expressed that they are enjoyed with fair promotional opportunities. Large per cent $(42.11$ per cent) of the employees in Food industries expressed that they are not enjoyed with promotional opportunities. Large per cent (53.33 per cent) of the employees in Electronics industries expressed that they are enjoyed with good promotional opportunities.

\section{vii) Compensation}

A large per cent of the employees in Food and Electrical industries expressed that they are not enjoyed with compensation in their industries. A large per cent (46.67per cent) of the employees in Electronics industries stated that they are enjoyed with good compensation. A small per cent of employees in Agro-based, Food, Chemical \& Engineering and Electrical industries expressed that they are enjoyed with good compensation. A small per cent of employees in Electronics industries stated that they are enjoyed with fair compensation.

\section{viii) Job Security}

A large per cent of the employees in Food and Electrical industries expressed that they are not enjoyed with job security in their industries. A large per cent ( 46.67 per cent) of the employees in Electronics industries stated that they are enjoyed with good job security. A small per cent of employees in Agro-based, Food, Chemical \& Engineering and Electrical industries expressed that they are enjoyed with good job security. A small per cent (13.33 per cent) of employees in Electronics industries stated that they enjoyed fair amount of job security.

\section{Commitment}

Commitment' is another concept which is closely related to 'Job Satisfaction'. It is generally believed that commitment of employees is the result of high satisfaction. Porter Steers and Mowday found a positive relationship between job satisfaction and commitment on 147 psychiatric technicians 42 . Other studies have also 
found that satisfaction has a consistent impact on absenteeism, but an ever more profound and consistent relationship on turnover. Another review found a negative correlationship of -0.40 between satisfaction and employee withdrawal leading the reviewer to the conclusion that satisfied people tend to be on the job more frequently and leave the organisation less frequently than those who are dissatisfied. Thus, there is growing enthusiasm for the view that organisational commitment is a better prediction of withdrawal behaviour on the part of employees than job satisfaction. These considerations prompted the researcher to undertake a study of commitment of employees working in small industry. High employee turnover is of considerable concern for the management because it disrupts normal operations, causes morale problems for those who stick on, and increases the cost involved in selecting and training replacements. The employer must do whatever possible to minimize turnover, make the employees feel satisfied on their jobs, and stay on.

Unlike the relationship between satisfaction and productivity, the connection between job satisfaction and employee turnover is established beyond doubt. It has been demonstrated that workers who have relatively low levels of job satisfaction are the most likely to quit their jobs and that organizational units with the lowest average satisfaction levels tend to have the highest turnover rates. However, the withdrawal behaviour of employees is modified by certain factors. Loyalty to the organization is one such behaviour. Some employment also influences turnover. If better avenues are available, an employee may not mind going in search of them, notwithstanding the present level of job satisfaction he enjoys. The present industrial culture is characterized by a work system which does not significantly stimulate workers to peak performance. It has led to a state where many individuals have become alienated and, consequently, have lost the zest for work. It has not helped individuals in gratifying their social and psychological needs of the individuals and has therefore generated feelings of subordination, dependence and submissiveness. It has also deemphasized self-actualization, growth process, creativity and innovativeness. The situation is still worse in the cases of small scale units where the workers, in the absence of job security and adequate work rewards, find it extremely difficult to satisfy their basic physiological needs continually. Research studies have also stated, in general, that many persons work today not because work offers any pleasure but there is no other way of earning a living. Increased employee alienation from the system of work is one of the important facts of work life these days. Under the circumstances, jobs do not seem to arouse interest or satisfaction among the employees.

Questions that reveal how committed the workers are in small scale units have been formulated for the purpose of this study. Factors such as low education of workers, employer's reluctance to free workers for interview schedules for a long time, inability of workers to fill the questionnaires independently compelled the researcher to avoid the scales developed for measuring commitment.

Ever since Kerr, et, al. formulated the different connections of commitment, there have been attempts to operationalize the concept in a meaningful manner. To avoid semantic confusion, commitment may be defined as a state where workers are positively oriented towards work in small industry, and identify themselves with the organization in which they are currently working.

\section{i) Did you ever think of leaving the organization?}

To this question, employees have given responses like frequently, now and then and never as shown in table 1.4. The table shows that majority of the employees in five categories of sample industries (61.40 percent) have given the answer 'frequently' indicating their inclination to leave the organization. There are more than one-fourth (28.07 per cent) of the employees who answered 'now and then' to the question. It is only a few (10.53 per cent) of the employees who said that they 'never' entertain any idea of leaving the organization.

TABLE 1.4

Employee Response Regarding Leaving The Organization

\begin{tabular}{|c|c|c|c|c|c|c|}
\hline $\begin{array}{l}\text { Responses } \\
\text { of employees }\end{array}$ & $\begin{array}{l}\text { Agro } \\
\text { based }\end{array}$ & Food & $\begin{array}{l}\text { Chemical \& } \\
\text { Engg }\end{array}$ & Electrical & Electronics & Total \\
\hline Never & $\begin{array}{l}5 \\
(15.62)\end{array}$ & $\begin{array}{l}10 \\
(17.54)\end{array}$ & $\begin{array}{l}7 \\
(6.09)\end{array}$ & $\begin{array}{l}4 \\
(7.84)\end{array}$ & $\begin{array}{l}4 \\
(13.33)\end{array}$ & $\begin{array}{l}30 \\
(10.53)\end{array}$ \\
\hline Now and then & $\begin{array}{l}7 \\
(21.88)\end{array}$ & $\begin{array}{l}13 \\
(22.81)\end{array}$ & $\begin{array}{l}22 \\
(19.13)\end{array}$ & $\begin{array}{l}32 \\
(62.75)\end{array}$ & $\begin{array}{l}6 \\
(20.00)\end{array}$ & $\begin{array}{l}80 \\
(28.07)\end{array}$ \\
\hline Frequently & $\begin{array}{l}20 \\
(62.50)\end{array}$ & $\begin{array}{l}34 \\
(59.65)\end{array}$ & $\begin{array}{l}86 \\
(74.78)\end{array}$ & $\begin{array}{l}15 \\
(29.41)\end{array}$ & $\begin{array}{l}20 \\
(66.67)\end{array}$ & $\begin{array}{l}175 \\
(61.40)\end{array}$ \\
\hline Total & $\begin{array}{l}32 \\
(100.00)\end{array}$ & $\begin{array}{l}57 \\
(100.00)\end{array}$ & $\begin{array}{l}115 \\
(100.00)\end{array}$ & $\begin{array}{l}51 \\
(100.00)\end{array}$ & $\begin{array}{l}30 \\
(100.00)\end{array}$ & $\begin{array}{l}285 \\
(100.00)\end{array}$ \\
\hline
\end{tabular}

Note: Figures in parentheses indicate percentages to totals. 
Across the different industries, it may be observed that it is in Chemical \& Engineering industry the problem is more severe in the sense that a highest percentage of employees (74.78) thought of leaving the organization frequently whereas the employees with the same with the same line of thinking are the least in Electrical industry (29.41 percent). Relatively speaking, Food industry appears to be better than other industries because it is in this industry more number of employees (17.54 percent) never thought of leaving the organization which shows their commitment. But in all other industries, greater evidence can be gathered to say that employees keep their eyes on more lucrative jobs elsewhere and are inclined to move out once the opportunity arises.

ii) Given a fresh opportunity, will you join in the same organization?

The employees were asked a different question as above to measure their commitment. The responses of the employees are shown in the table 1.5.

TABLE 1.5

Employees Response Regarding Their Joining In The Same Organization When A Fresh Opportunity Is Given

\begin{tabular}{|l|l|l|l|l|l|l|}
\hline $\begin{array}{l}\text { Responses } \\
\text { of } \\
\text { employees }\end{array}$ & $\begin{array}{l}\text { Agro } \\
\text { based }\end{array}$ & Food & $\begin{array}{l}\text { Chemical \& } \\
\text { Engg }\end{array}$ & Electrical & $\begin{array}{l}\text { Electronic } \\
\text { s }\end{array}$ & Total \\
\hline Yes & $\begin{array}{l}4 \\
(12.50)\end{array}$ & $\begin{array}{l}9 \\
(15.79)\end{array}$ & $\begin{array}{l}8 \\
(6.96)\end{array}$ & $\begin{array}{l}3 \\
(5.88)\end{array}$ & $\begin{array}{l}5 \\
(16.67)\end{array}$ & $\begin{array}{l}29 \\
(10.18)\end{array}$ \\
\hline No & 19 & 33 & 76 & 10 & 7 & 145 \\
& $(59.38)$ & $(57.89)$ & $(66.09)$ & $(19.61)$ & $(23.33)$ & $(50.88)$ \\
\hline No Idea & 9 & 15 & 31 & 38 & 18 & 111 \\
& $(28.12)$ & $(26.32)$ & $(26.95)$ & $(74.51)$ & $(60.00)$ & $(38.94)$ \\
\hline Total & $\begin{array}{l}\mathbf{3 2} \\
(\mathbf{1 0 0 . 0 0})\end{array}$ & $\begin{array}{l}\mathbf{5 7} \\
(\mathbf{1 0 0 . 0 0})\end{array}$ & $\begin{array}{l}\mathbf{1 1 5} \\
(\mathbf{1 0 0 . 0 0})\end{array}$ & $\begin{array}{c}\mathbf{5 1} \\
(\mathbf{1 0 0 . 0 0})\end{array}$ & $\begin{array}{l}\mathbf{3 0} \\
(\mathbf{1 0 0 . 0 0})\end{array}$ & $\begin{array}{c}\mathbf{2 8 5} \\
(\mathbf{1 0 0 . 0 0})\end{array}$ \\
\hline
\end{tabular}

Note: Figures in parentheses indicate percentages to totals.

It is interesting to observe from the table that one-half of the employees in all the sample industries expressed their 'No' to joining the same organization when a fresh opportunity is given to them. Obviously, it shows their dislike and dissatisfaction. Nearly two-fifths answered that they have 'no idea'. An affirmative answer was given only by one-tenth of the employees. If we further analyze across industries, it is becoming clear that it is in Chemical \& Engineering industry, Agro based industry and Food industry, the reluctance to join back is more with a large number of employees saying 'No'. Then Electrical and Electronics industries are a little better where the number of employees saying 'No' is less. Most of the employees in these two industries preferred to say 'no idea', which is better than saying an emphatic 'No'.

On the whole, the above analysis clearly comes out with ample evidence to make an inference that employees in the small scale industries under study are not very much committed. Hence the employers in these industries should take note of it and implement attractive measures for retaining the employees and by changing their attitudes and dispositions.

iii) If the job opportunity arises, will you put your children in the same organization?

There is yet another measure used to study the commitment of employees in the selected small units. An indirect question was put to them as above and the responses of the employees are indicated in table 1.6.

TABLE 1.6

Employees' Response Regarding Joining Their Children In The Same Organization When Job Opportunity Arises

\begin{tabular}{|c|l|l|l|l|l|l|l|}
\hline $\begin{array}{l}\text { Responses of } \\
\text { employees }\end{array}$ & Agro based & Food & $\begin{array}{l}\text { Chemical \& } \\
\text { Engg }\end{array}$ & Electrical & Electronics & Total \\
\hline Yes & $\begin{array}{l}5 \\
(15.63)\end{array}$ & $\begin{array}{l}6 \\
(10.52)\end{array}$ & $\begin{array}{l}4 \\
(3.48)\end{array}$ & $\begin{array}{l}5 \\
(9.80)\end{array}$ & $\begin{array}{l}(10.00) \\
(8.07)\end{array}$ \\
\hline No & $\begin{array}{l}20 \\
(62.50)\end{array}$ & $\begin{array}{l}40 \\
(70.18)\end{array}$ & $\begin{array}{l}82 \\
(71.30)\end{array}$ & $\begin{array}{l}11 \\
(21.57)\end{array}$ & $\begin{array}{l}(33.33) \\
(57.19)\end{array}$ \\
\hline
\end{tabular}




\begin{tabular}{|l|l|l|l|l|l|l|}
\hline No Idea & 7 & 11 & 29 & 35 & 17 & 99 \\
& $(21.87)$ & $(19.30)$ & $(25.22)$ & $(68.63)$ & $(56.67)$ & $(34.74)$ \\
\hline Total & $\mathbf{3 2}$ & $\mathbf{5 7}$ & $\mathbf{1 1 5}$ & $\mathbf{5 1}$ & $\mathbf{3 0}$ & $\mathbf{2 8 5}$ \\
& $\mathbf{( 1 0 0 . 0 0 )}$ & $\mathbf{( 1 0 0 . 0 0 )}$ & $\mathbf{( 1 0 0 . 0 0 )}$ & $\mathbf{( 1 0 0 . 0 0 )}$ & $\mathbf{( 1 0 0 . 0 0 )}$ & $\mathbf{( 1 0 0 . 0 0 )}$ \\
\hline
\end{tabular}

Note: Figures in parentheses indicate percentages to totals.

If we read the table carefully, we find that the responses to this question are no better than those for the previous question. More than one-half of the respondents express their unwillingness to join their children in the same organization given an opportunity with an emphatic 'No'. Those that are affirmative to this question are very few ( 8.07 percent). If we look at industry-wise, reluctance to join their children in the same organization given an opportunity is more in Chemical \& Engineering, Food and Agro based industry in the same order whereas in Electrical and Electronics industries majority were not in a position to take any stand and remained ambivalent.

In any case, the above analysis speaks eloquently of the lack of commitment on the part of existing employees working in different small scale industries. In the face of competition from large industry for skilled and talented employees, the task of employers in small industry is more challenging. They should be able to carve out a niche market of their own within which they should be able to attract and retain employees by appropriate measures.

\section{Major Observations}

It may be observed that respondents are not very happy with the compensation available for them in small industries. Because it is only a few (about one-fourth) who regarded their compensation to be good. As much as two-fifths of employees are not happy. While the employers in small scale industries cannot pay on par with large organizations, at least they should make employees gain the feeling of equity. If not good, a sizeable section of employees should consider their compensation to be fair. It is particularly important in view of the spiraling prices that impact the purchasing capacity of employees.

It may be noted that it augurs well for these small units to have such employees with a positive perception about their supervisor's treatment. A few (23.16 per cent) however, expressed that their supervisors are dictatorial and demanding. Industry-wise also, most of the employees in all the industries held positive disposition towards their supervisors. This is what the employers should always try to foster in their respective units. The employers particularly in Electronics industry should make further endeavors towards improving the supervisory styles in order to make employees turn in the positive direction.

It may be stated that majority of the employees (58.24 per cent) in all sample industries stated that their relations with co-workers are friendly and helpful. Among the remaining, 15.79 per cent of the employees stated that their relations with co-workers are unfriendly and unhelpful and what is more, about one-fourth of the employees even described their co-workers to be selfish and not trustworthy.

It may be observed that Management is not supportive in three industries viz., Electronics industry (76.66 per cent) Food industry (70.17 per cent), and Agro-based industry (68.75 per cent), majority of employees felt that their managements are not supportive. Therefore, the employers in these three industries should learn a lesson out of it and come forward with several measures by which they are interpreted by employees as supportive. This will go a long way in not only motivating employees but also in promoting cordial relations with them.

It may be viewed that majority of the employers did not repose their faith in HRP. However, recent developments in small scale industry such as modernization, increased competition from large scale units and the resultant need to maintain quality and precision in their products, the availability of jobs demanding specialized skills (for instance, electronics and engineering sectors) demand a serious rethinking on the part of the employers with regard to HRP. It is strongly advocated even in small industry because it helps the employers to obtain and retain the quality and quantity of manpower they require from time to time.

It may be concluded that respondents are not very happy with the compensation available for them in small industries. Because it is only a few (about one-fourth) who regarded their compensation to be good. As much as two-fifths of employees are not happy. While the employers in small scale industries cannot pay on par with large organizations, at least they should make employees gain the feeling of equity.

Regarding the promotional opportunities, two- thirds of employees covered in the study saw no such chances available in their units. While one-fifth said that they were already promoted, the remaining (one-tenth) said they were still expecting promotions. Therefore, in respect of promotions, there is much to be desired. The employers should be able to create more opportunities of promotions for their employees in order to make employees feel committed. A small per cent of the employees in Food, Chemical \& Engineering and Electrical industries expressed that they are enjoyed good promotional opportunities in their industries.

There is ample evidence available to make an inference that employees in the small scale industries are not very much committed. In the face of competition from large industry for skilled and talented employees, the 
task of employers in small industry is more challenging. They should be able to carve out a niche market of their own within which they should be able to lure and retain employees.

Regarding the congeniality of work environment, more than one-third of the employees in all the small scale industries stated that the work environment in their units was moderate and as many number of employees viewed it to be unfavorable. Those who admitted the existence of congenial work environment constituted a small percentage only. Unfortunately, not many have realized the importance of rewarding employee performance in a systematic manner. It is small wonder, majority of the employees were dissatisfied with what they had received in return for their services. The reward systems were neither tied to employee performance nor were tailored to the needs of individuals. Large per cent of the employees in Electrical and Electronics industries stated that they are congenial with work environment.

It may be stated that majority of employees did not enjoy job security in Food (43.85 per cent) and Electrical (41.18 per cent) industries. Majority of the employees in Agro (40.63 per cent) and Chemical \& Engineering (46.09 per cent) industries enjoyed job security to some extent. Majority of the employees in Electronics (53.33 per cent) industries are enjoyed job security to a large extent.

\section{References}

[1] Ashim Kumar Das \& Nikhil Bhusan Dey., " Effective Management of Receivables in Small Business”, SEDME, Vol.31, No.1, March,2004 pp.17-23.

[2] Agrawal R.K.” Energy Efficiency and Waste Minimisation in the Small/ Medium scale Industries, SEDME, Vol.30, No.2, June, ,June 2003, pp.39-53.

[3] Anantha K.H. \& Jayasheela \& Vishwanatha, "Small Scale Industries in India: Are They Contributing Enough?", SEDME, Vol.31, No.4, December,2004.pp.73-80. Anbumani V and S. Ganesan,” A Study of Growth, Marginal Productivities, MRS, Factor and Elasticity of substitution in Small Metal Product Industry",SEDME, Vol.29, No.2, 2002 June, pp.45-58.

[4] Anil Kumar and M.C.Garg'Financing of Small Scale Industriesin Haryana by Haryana Financial Corporation(HFC) during post reform period",SEDME, Vol.29, No.1, March,2002, pp.43-55.

[5] Behaviour, Objectives and Perfrmance of Small Scale Industries in Karnataka", SEDME, Vol.29, No.1, 2002 March, pp1-15. 146.

[6] Bisnt, N.S., participative Management in India, Shri Publishing House, Delhi, 1986.

[7] Chowdary Mukthar Singh 'Cottage and small scale industries' Read Book Publications, Hyderabad, 2007.

[8] Dinesh P.T. \& Jayasheela \& Basil Hans.V "Micro, Small and Medium Enterprises in India: Trernds and Challenges", SEDME, Vol.35, No.2, June,2008,pp.37-46.

[9] Frank Sunil Justus T. \& M. Ramesh," Rubber Plantations: Growth and Prospects of Small Holders" SEDME, Vol.34, No.3, September,2007, pp.43-51.

[10] Gusharan Varandane, workers' participation in Management, Deep and Deep, New Delhi, 1987.

[11] Hyderabad R.L. \& Praveen Korbu "Determinants of Capacity Utilisation in SSI Sector : A Case Study: SEDME, Vol.35, No.2, June,2008,pp.37-46..

[12] Inder Jeet Dagar, "Industrial Relations in small scale Industry- A Study of Internal Factors", The Indian Journal of Commerce, Vol. 56, No.1, January-March 2003, pp.68-78.

[13] Inder Jeet Dagar," Industrial Relations in Small Scale Industry", the Indian Journal of Commerce, Vol.56, No.1, Jan-Mar, 2003.

[14] Jyothi.P," Practices of HR Functions in a Small Scale Organization”, SEDME, Vol.31, No.4, December 2004 pp.19-26.

[15] Kowjalgi V.R,"SMALL Scale In dustries in India-A Brief Case Study” SEDME, Vol.27, No.1, March,2000, pp.73-81.

[16] Mohd Israrul Haque., "Job Satisfaction of Indian Academicians: A Study Based on Gender and Age", the Indian Journal of Commerce. Vol. 57, No.2, Apr-Jun, 2004, PP.102-113.Prasad, V.N, “ Small Service Enterprises Need Government's Interventions”, SEDMI, Vol.35, No.3, September 2008, pp.10.

[17] Reddy, T.S., 'A Review of Literature on Small Scale Industry', Mimeo Sri Kushnadevaraye University, Anantapur; 1985.Raghuram A,’Small Scale Industries in Kerala- Competitiveness and Challenges Under Globalisation”, SEDME, Vol.31, No.2, 2004 June, pp.7-17.

Journals

Laghu Udyog Samachar, focus on Tenth Plan : SSI and Employment April-September.

Small Industries Development Bank of India (SIDBI), 2002. SIDBI Report on Small Scale Industrial Sector 2001.Lucknow, 257-258.

Indian Journal of Applied Psychology

Indian Journal of industrial Relations

Indian Journal of Training \& Development Management and Change

\section{DAILIES}

Business Times

Economic and Times of India

Financial Express

News Letter of DIC

\section{WEBSITES}

www..ssi. Com, www.sido. Com, www.nisiet. Com, 